\title{
The Separation of Territory and State: a Digital French Revolution?
}

\author{
Yussef Al Tamimi
}

The contributions on cloud communities and citizenship in this blog raise both hopes and fears. The reality of an idea initially as outlandish as citizens of a digital cloud is materialising as we ponder and debate its practices. Political theory and the law must attempt to keep up with these rapidly changing circumstances. This comment raises some questions regarding three assumptions in this debate:

\section{Cloud states ${ }^{1}$ have no territory \\ 2. Cloud states cannot exert violence \\ 3. Cloud state membership is based on choice}

To illustrate and perhaps formulate a response to these assumptions, it might benefit this futuristic debate to consult experiences from the past. As suggested by the other contributors, the current transformation of the state as a consequence of the 'digital revolution' is profound. Nothing less than a separation of the state from its traditional connectedness to territory is suggested. The historic event that comes close to matching such a seismic shift in the structure of the state was the American and French Revolutions, which set in motion the institutional untying of state and church. A historical parallel is quickly drawn: if these revolutions led to the separation of Church and State that resulted in secular states, will the digital revolution lead to the separation of Territory and State that results in cloud states?

1 I use the term 'cloud state' rather than 'cloud community', as the latter unnecessarily obscures the fact that, at least in this debate, the question is whether clouds can fulfill certain political functions traditionally belonging to the state, such as conferring citizenship. Assuming that these political functions can indeed be performed by clouds, this leaves no reason to call a cloud anything else than a 'state', except to dissociate the cloud from the negative connotations of the state and calling it by the more cozy term community. However, in my opinion, one should not appropriate the political function of the traditional state and simultaneously obscure the responsibility - which states sometimes fail to exercise - that is inherent to that function. 


\section{Assumption 1: Cloud states have no territory}

Robert Post, focusing on legislation in his blog post, argues: 'A world in which every community is voluntary is a world in which every norm is also voluntary. It is therefore a world without law. Because politics is the social form by which we create law, it is also a world without politics.'

For Post, a cloud state, which does not impose legislation, is not a state at all. One can imagine that arguments sounding very similar were once raised by opponents of the separation of Church and State: 'a secular, neutral state, which does not impose public morals, is not a state at all.' I raise this parallel not to disagree with Post. Rather, it is to show that after centuries of debate on secularism we have come to understand that 'neutrality' of the state is an impossibility; a state always makes choices that impact a state's public sphere. That is to say that the opponents of the separation of Church and State were wrong in the first place because the starting premise of their critique, that the secular state would be neutral, was incorrect.

The starting premise of the cloud state is that it is nonterritorial. Now that we have come to know that 'neutrality' does not really exist, the question arises if we have to conclude that 'nonterritorial clouds' do not really exist either. In other words, is the cloud itself not territory? I do not mean this in the strict physical sense that clouds have servers that are located in territorial states, which itself is a valid point; yet the development of serverless cloud computing in the future might undermine such an argument. To think of the cloud as somehow territory-less and border-less is incongruous if one appreciates that territory itself is not a natural phenomenon but a man-made construct the meaning of which is dynamic and can come to encompass non-physical spaces.

\section{Assumption 2: Cloud states cannot exert violence}

Focusing on violence in his comment, Michael Blake states: 'My own challenge is broader: the protection of human rights, I believe, can only be accomplished by means of violence and force, in both policing and in punishment - and this violence is in our world reserved (as a matter of right, if not reality) for use by states.'

Blake argues that cloud states cannot protect human rights. A comparison with anti-separationists in the French Revolution is again not far away: they 
would claim that 'secular states cannot protect God's law'. To make his argument, Blake relies heavily on state force. But why could cloud states not impose their own forms of digital violence? Perhaps an obvious damage they could inflict is to one's reputation. An example of this is the social credit system proposed by the Chinese government, which is a national reputation system that assigns social credit to citizens. The flipside of such reputation systems that aim to promote 'good citizenship' behaviour is the potential social devaluation of 'bad' citizens, which can go as far as seriously harming their wellbeing and possibilities in life. A punishment in terms of such social devaluation imposed by the cloud state is conceivably more painful and restricting to the individual than traditional methods of punishment, such as fines or jail.

As with territory, one could counter this claim by saying that what matters for statehood is physical, rather than non-physical, violence. In that case, the actual core of the matter is the physicality of the traditional state's territory and violence compared to the non-physicality of the cloud state's territory and violence. That raises a question that is yet to be addressed by proponents of cloud states: What is desirable about the non-physicality of territory and violence that makes cloud states and their citizenship superior to traditional states and their citizenship?

\section{Assumption 3: Cloud state membership is based on choice}

Focusing on the idea of consent-based cloud communities, Rainer Bauböck writes: 'My response is that this would be fatal for democracy. Already Aristotle knew that, unlike families, democratic polities are associations of diverse individuals. The territorial bases and automatic attribution mechanisms of citizenship create political community among individuals that differ profoundly in their interests, identities and ideas about the common good.'

In short, for Bauböck choice cannot be constitutive for political membership (citizenship). Hence, the chosen membership of cloud states is not citizenship. This is a difficult topic, and the parallel with the earlier (French) revolution escapes me. The reason for this is that in the secular revolution separating Church and State the 'onus' of choice fell on the Church and not the State: It was religion and the freedom to choose individually one's religion that was guaranteed by the secular state. By contrast, in the digital revolution separating Territory and State the opening up of choice is focused 
on the newfound states among which individuals can choose. In fact, one might even be limited in exiting from a territory (think refugees, political activists) yet have the freedom to select from a range of cloud states one wants to join.

Yet, the notions of choice and voluntariness applied in this context leave many questions unanswered. It is still unclear in what way we understand membership in a cloud state to be a 'choice'. The Chinese social credit system mentioned earlier may become mandatory as of 2020. Such a turn towards explicitly mandatory membership will probably not always happen, but what idea of choice do we have in mind when saying that cloud membership is a 'choice'? Is it rational choice theory, which has long been refuted in psychology? The conditions that move people to decide on their cyber membership, as well as their non-rational motivations, have to be taken into account for a more realistic conception of choice.

The question of chosen membership is closely related to issues concerning identity. The idea that individuals are able to 'create' their own identities, which is implicit in Liav Orgad's contribution, is mistaken. Iris Marion Young makes a helpful distinction between associations and social groups to tease out the distinct role of identity when membership is based on choice. Young argues that that the contract model of society applies to associations but not to social groups: 'Individuals constitute associations; they come together as already formed persons and set them up, establishing rules, positions, and offices.' (my emphasis). ${ }^{2}$ In contrast, social groups, in which our identities are implicated, involve a much more complex process: 'Group affinity $(\ldots)$ has the character of (...) "thrownness": one finds oneself as a member of a group, whose existence and relations one experiences as always already having been.' This does not mean that one cannot change one's group affinity, for example by changing one's gender identity as transpersons do. For Young, these cases illustrate thrownness precisely because such changes are 'experienced as a transformation in one's identity.' This phenomenological approach to social groups shows that a deeper affinity is involved in the process of membership and that social groups, which implicate our identity, cannot be explained solely by 'choice'. Young and Bauböck therefore agree that citizenship and choice are irreconcilable, though they do so from different standpoints: for Bauböck the presence of choice in communities leads to a democratic deficit, for Young it leads to a social defi-

2 Young, I. M. (1989), 'Polity and Group Difference: A Critique of the Ideal of Universal Citizenship', Ethics 99: 250-274, at 260. 
cit, a lack of social affinity or belonging. To respond to this complex debate relating to membership, the nature of cloud membership requires further clarification as to its position on citizenship, identity and choice.

Open Access This chapter is licensed under the terms of the Creative Commons Attribution 4.0 International License (http://creativecommons.org/licenses/by/4.0/), which permits use, sharing, adaptation, distribution and reproduction in any medium or format, as long as you give appropriate credit to the original author(s) and the source, provide a link to the Creative Commons license and indicate if changes were made.

The images or other third party material in this chapter are included in the chapter's Creative Commons license, unless indicated otherwise in a credit line to the material. If material is not included in the chapter's Creative Commons license and your intended use is not permitted by statutory regulation or exceeds the permitted use, you will need to obtain permission directly from the copyright holder.

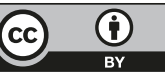

